\title{
Late-summer fire and follow-up herbicide treat- ments in tallgrass prairie
}

\author{
DAVID M. ENGLE, J.F. STRITZKE, TERRENCE G. BIDWELL, AND P.L. CLAYPOOL
}

\begin{abstract}
Authors are professor of range science, professor of weed science, and associate professor of range science, Division of Agricultural Sciences and Natural Resources, and professor, Department of Statistics, Oklahoma State University, Stillwater 74078.
\end{abstract}

\begin{abstract}
Research on fire in tallgrass prairie focuses almost exclusively on dormant season fires, primarily in winter and spring. Relatively little is known about the response of tallgrass prairie vegetation to growing-season fires or follow-up management. We evaluated vegetation response of grazed, high-seral tallgrass prairies to herbicides after late-summer burning. Dry matter yields of little bluestem [Schizachyrium scoparium (Michx.) Nash], other perennial grasses, total perennial grasses, and total herbage were significantly reduced by late-summer burning. Tallgrass and annual grass standing crop did not differ between burn treatments. Forb standing crop on burned plots averaged about twice that of unburned plots. Follow-up treatment with 2,4-D [(2,4-dichlorophenoxy)acetic acid] significantly reduced forb standing crop compared to atrazine [6-chloro-N-ethyl- $\mathrm{N}^{\prime}$-(1-methylethyl)-1,3,5-triazine-2,4-diamine]. Standing crop of tallgrasses and total perennial grasses was greater on plots treated with 2,4-D than on plots treated with no herbicide or with atrazine. Because late-summer burning did not severely reduce herbage production nor drastically alter community composition for more than 1 year, late-summer burning may be a viable alternative for brush control and for improving wildlife habitat in high-seral tallgrass prairie. If management objectives require reduced forb production and increased perennial grass production following late-summer burning, application of 2,4-D would be an appropriate management practice.
\end{abstract}

Key Words: atrazine, burning, 2,4-D, herbicides, range improvement, tallgrasses, true prairie, wildfire

This is journal 6357 of the Oklahoma Agricultural Experiment Station. Manuscript accepted 28 May 1993.
Season of burning can have a major effect on tallgrass prairie response to fire (Owensby 1985). Tallgrass prairie fuels are flammable much of the year so wildfire can occur throughout the year, including the growing season, when much of the fine fuel is green (Bragg 1982). Launchbaugh and Owensby (1978) noted accidental range fires occur each year throughout Kansas. The voluminous research on fire in tallgrass prairie focuses almost exclusively on dormant season fires, primarily in winter and spring. This research forms an extensive knowledge base on the effects of prescribed spring burning in North American tallgrass prairies.

Late spring burns are often prescribed to benefit cattle production (Anderson et al. 1970, Owensby and Smith 1979), because they favor the matrix tallgrasses over forbs, low-seral grasses, and woody species (McMurphy and Anderson 1965, Anderson et al. 1970, Bragg and Hulbert 1976, Towne and Owensby 1984, Abrams 1986, Abrams et al. 1986). Earlier dormant season burns in the Kansas Flint Hills generally increase plants less desirable for livestock production at the expense of desired tallgrasses (Launchbaugh and Owensby 1978, McMurphy and Anderson 1965, Towne and Owensby 1984). This may not be true for other tallgrass prairies (Bidwell et al. 1990). Late-spring annual burning in Kansas Flint Hills tallgrass maximizes herbage yield and composition of the matrix tallgrasses compared to burning earlier in the dormant season (McMurphy and Anderson 1965, Towney and Owensby 1984). The response of tallgrass prairie to growing-season fire is the subject of relatively few studies (Anderson 1972, Adams et al. 1982, Ewing and Engle 1988). The response of tallgrass prairies to herbi-

JOURNAL OF RANGE MANAGEMENT 46(6), November 1993 
Table 1. Dates of treatments, activation of atrazine, and dates of standing crop for 2 experiments.

\begin{tabular}{|c|c|c|c|c|c|c|c|}
\hline & \multirow{2}{*}{$\begin{array}{l}\text { Burning } \\
\text { dates }\end{array}$} & \multirow{2}{*}{$\begin{array}{c}2,4-\mathrm{D} \\
\text { treatments }\end{array}$} & \multirow{2}{*}{$\begin{array}{l}\text { Atrazine } \\
\text { treatments }\end{array}$} & \multirow{2}{*}{$\begin{array}{l}\text { Atrazine } \\
\text { activation }^{1}\end{array}$} & \multicolumn{3}{|c|}{ Clipping data } \\
\hline & & & & & 89 & 90 & 91 \\
\hline $\begin{array}{l}\text { Experiment } 1 \\
\text { Experiment } 2\end{array}$ & $\begin{array}{l}9 / 9 / 88 \\
9 / 8 / 89\end{array}$ & $\begin{array}{l}5 / 11 / 89 \\
5 / 10 / 90\end{array}$ & $\begin{array}{c}3 / 27 / 89 \\
3 / 5 / 90\end{array}$ & $\begin{array}{l}3 / 28 / 89 \\
3 / 11 / 90\end{array}$ & $7 / 19$ & $\begin{array}{l}7 / 22 \\
7 / 22\end{array}$ & $7 / 25$ \\
\hline
\end{tabular}

'Date on which precipitation in a single event exceeded $2.5 \mathrm{~cm}$.

cides after growing-season fire also is not well documented.

Research on growing-season burns, i.e., summer burning, and management following growing-season burns is needed to increase the knowledge base on fire effects and fire management in tallgrass prairies. Decisions on managing prairies after accidental or planned fire in the growing season and the early dormant season currently relies on inferences from research on dormant season burns (see Launchbaugh and Owensby 1978, p. 26). Furthermore, prescribed summer burning has been suggested as an option for brush control (Anderson 1981), but we have an inadequate base of knowledge to predict plant community responses to these burns. Our objectives in this study were to determine the response of previously grazed, high-seral tallgrass prairie to burning in late summer, and to evaluate vegetation response of the burned prairies after treating with herbicides.

\section{Materials and Methods}

Two experiments (1988, Experiment 1; 1989, Experiment 2) were conducted in a tallgrass prairie located on the Oklahoma State University Research Range approximately $15 \mathrm{~km}$ west southwest of Stillwater, Okla. Mean annual precipitation is $81 \mathrm{~cm}$ (Meyers 1982). The study area is on a shallow prairie range site in the Central Rolling Red Prairies Land Resource Area (USDA Soil Conservation Service 1981). The soil is a Grainola clay loam with a clay B horizon (fine, mixed thermic Vertic Haplustalf). The study area vegetation was in a late sere dominated by big bluestem (Andropogon gerardii Vitman), switchgrass (Panicum virgatum L.), indiangrass [Sorghastrum nutans (L.) Nash], and little bluestem [Schizachyrium scoparium (Michx.) Nash.]. Experiment 1 was grazed season-long at a moderate stocking rate (approximately 2.5 AUM ha $^{-1}$ ) by stocker cattle in 1987 and in 1988 before the burning treatments were applied in September 1988. Experiment 2 , located in the same pasture, was grazed season-long by stocker cattle in 1989 at approximately $2.5 \mathrm{AUM} \mathrm{ha}^{-1}$ before the burning treatments were applied in September 1989. Cattle were excluded from the plots in each of the experiments after treatment.

Burning treatments in Experiments 1 and 2 were applied to $10 \times$ 20 -m plots in September 1988 and in September 1989, respectively (Table 1). Burning treatments were replicated in a completely randomized design with 5 to 7 replications. Plots were ignited with a drip torch at plot boundaries that were oriented with the long axis in the prevailing wind direction.

Fire behavior and fire temperature were measured on 4 plots ( 2 headfires and 2 backfires) of the 9 Sept. 1988 burns and 4 plots ( 2 headfires and 2 backfires) of the 8 Sept. 1989 burns. Rate of spread $\left(\mathrm{m} \mathrm{s}^{-1}\right)$ was measured with a stopwatch (Britton et al. 1977). Fireline intensity (Byram 1959) was computed as the product of the fuel low heat of combustion $\left(\mathrm{kJ} \mathrm{kg}^{-1}\right)$, the weight of the fuel consumed $\left(\mathrm{kg} \mathrm{m}^{-2}\right)$, and rate of spread. Low heat of combustion was the average value $\left(15,830 \mathrm{~kJ} \mathrm{~kg}^{-1}\right)$ from Bidwell and Engle (1991) for similar tallgrass prairie fuels, adjusted for moisture content of the fuel. Heat per unit area $\left(\mathrm{kJ} \mathrm{kg}^{-2}\right)$ was calculated from fireline intensity and rate of spread as described by Rothermel and Deeming (1980). Fire temperature traces were recorded at 3 stations per plot at 0 and $60-\mathrm{cm}$ above the soil surface as described by Engle et al. (1989). Parameters derived from the temperature traces included maximum temperature, residence time, and degree seconds.

Fuel load was estimated by weighing clipped herbaceous material from 5 quadrats $(0.5$ by $0.5 \mathrm{~m})$ per plot. Fuel moisture, expressed on a dry weight basis, was determined after samples were oven dried at $70^{\circ} \mathrm{C}$ for 72 hours. Ambient air temperatures and relative humidity were measured with a sling psychrometer. Wind speed at $2 \mathrm{~m}$ above the soil surface was measured with a totalizing anemometer.

After burning, burn plots were divided into three $6.7 \times 10-\mathrm{m}$ subplots for herbicide treatments (no herbicide, atrazine [6-chloro$\mathrm{N}$-ethyl-N'-(1-methylethyl)-1,3,5-triazine-2,4-diamine] at $1.12 \mathrm{~kg}$ a.i. ha ${ }^{-1}$, or the butoxyethyl ester of 2,4-D [2,4-dichlorophenoxy)acetic acid] at $0.84 \mathrm{~kg}$ a.e. $\mathrm{ha}^{-1}$ ). Herbicides were applied with a compressed air bicycle sprayer. Dates of herbicide application are listed in Table 1. Unburned check plots received no herbicide treatments. Thus, we compared burned and unburned treatments (neither with follow-up herbicide) and we compared 3 follow-up management treatments after burning (no herbicide, atrazine, and 2,4-D).

Both experiments were evaluated for 2 growing seasons after burning (Table 1). The response of herbage components to treatments was determined by clipping in mid-July. The residual treatment effects were assessed by clipping herbage in mid-July of the second year. Herbage was clipped to ground level in three $0.2 \times$ $0.5-\mathrm{m}$ quadrats within each subplot and hand-separated into current year's herbage and litter and mulch. Current year's herbage was separated into little bluestem, tallgrasses (big bluestem, indiangrass, and switchgrass), other perennial grasses, annual grasses, and forbs. Herbage was dried at $65^{\circ} \mathrm{C}$ for 72 hours and weighed. For data analysis, all current year's herbage components, other than annual grasses and forbs, were combined into 1 category (perennial grasses). Second year measurements were selected at random from areas that had not been clipped the previous year.

Data were ranked before conducting analysis of variance as described in SAS Institute Inc. (1988) for nonuniformly distributed data in a completely randomized design. Because the design was unbalanced, we used the Type I sum of squares in the SAS PROC GLM. The model was a split-plot in 2 environments (i.e., experiments) with years of measurement serving as split plots and with years nested within experiments as suggested by Carmer et al. (1989). Levels of the main factor were burn and herbicide combinations. The first analysis was a comparison of burn and no burn without herbicides and the second analysis was a comparison of herbicides in burned plots. The least significant difference test protected by a significant $(P<0.05)$ F-test was used to test differences among least squares means of herbicide treatments.

\section{Results}

\section{Burning Conditions}

Precipitation was below normal in each of the 4 growing-season months before the 1988 burns of Experiment 1 (Table 2). The resulting burning conditions for Experiment 1 (Table 3) resulted in intense fires (Table 4). In contrast, precipitation was above average in each of the 4 growing-season months preceding the 1989 burns of Experiment 2. Water content of fuels in Experiment 2 was $76 \%$ compared to only $17 \%$ for Experiment 1 (Table 3). Thus, fires were 
Table 2. Precipitation (cm) in a tallgrass prairie and long-term average precipitation at Stillwater, Okla. for the years of treatments and measurements.

\begin{tabular}{|c|c|c|c|c|c|}
\hline Month & 1988 & 1989 & 1990 & 1991 & $\begin{array}{c}\text { Long-term } \\
\text { average }\end{array}$ \\
\hline & \multicolumn{5}{|c|}{ 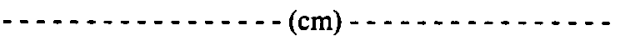 } \\
\hline Jan. & 3.6 & 4.2 & 4.7 & 2.5 & 2.8 \\
\hline Feb. & 0.9 & 4.3 & 9.7 & 0.2 & 3.2 \\
\hline Mar. & 13.9 & 9.5 & 18.2 & 2.5 & 5.6 \\
\hline Apr. & 10.4 & 0.4 & 14.9 & 8.0 & 8.5 \\
\hline May & 6.9 & 17.2 & 12.2 & 17.9 & 12.3 \\
\hline Jun. & 3.3 & 13.9 & 2.6 & 10.2 & 10.2 \\
\hline Jul. & 6.8 & 11.2 & 3.7 & 1.1 & 7.7 \\
\hline Aug. & 2.5 & 12.8 & 9.1 & 3.6 & 7.6 \\
\hline Sept. & 19.8 & 12.3 & 9.7 & 14.5 & 9.5 \\
\hline Oct. & 3.9 & 7.2 & 3.1 & 10.8 & 7.1 \\
\hline Nov. & 8.8 & 0 & 4.4 & 6.9 & 5.2 \\
\hline Dec. & 2.4 & 1.3 & 2.5 & 13.0 & 3.4 \\
\hline Annual & 83.1 & 94.3 & 95.0 & 91.0 & 83.0 \\
\hline
\end{tabular}

Table 3. Weather and fuel conditions associated with burning treatments in a tallgrass prairie in northcentral Oklahoma.

\begin{tabular}{lccc}
\hline \hline & Experiment 1 & & Experiment 2 \\
\cline { 2 - 2 } & Late-summer & & Late-summer \\
\hline Air temperature $\left({ }^{\circ} \mathrm{C}\right)$ & $31-33$ & & $33-34$ \\
Relative humidity $(\%)$ & $26-36$ & & $48-50$ \\
Windspeed $\left(\mathrm{km} \mathrm{h}^{-1}\right)$ & $6-13$ & & $13-14$ \\
Standing fuel $\left(\mathrm{kg} \mathrm{ha}^{-1}\right)$ & 5890 & & 5380 \\
Fallen fuel $\left(\mathrm{kg} \mathrm{ha}^{-1}\right)$ & 2790 & & 2330 \\
Fuel moisture $(\%)$ & 17 & \\
\hline
\end{tabular}

Table 4. Behavior of fires in a tallgrass prairie in northcentral Oklahoma. Values in parentheses are standard errors.

\begin{tabular}{lcc}
\hline & Experiment 1 & Experiment 2 \\
\hline Fire behavior & $1830(880)$ & $380(140)$ \\
Fireline intensity $\left(\mathrm{kW} \mathrm{m}^{-1}\right)$ & $8.0(3.7)$ & $2.0(0.7)$ \\
Rate of spread $\left(\mathrm{min}^{-1}\right)$ & $12990(690)$ & $9360(1540)$ \\
Heat per unit area $\left(\mathrm{kJ} \mathrm{m}^{-1}\right)$ & & \\
Degree seconds & $36204(6146)$ & $13185(4176)$ \\
$0 \mathrm{~cm}\left({ }^{\circ} \mathrm{C} \times \mathrm{s}\right)$ & $13826(1379)$ & $10833(2079)$ \\
$60 \mathrm{~cm}\left({ }^{\circ} \mathrm{C} \times \mathrm{s}\right)$ & & \\
Maximum temperature & $411(61)$ & $174(70)$ \\
$0 \mathrm{~cm}\left({ }^{\circ} \mathrm{C}\right)$ & $374(41)$ & $206(29)$ \\
$60 \mathrm{~cm}\left({ }^{\circ} \mathrm{C}\right)$ & & \\
Residence time & $371(43)$ & $428(48)$ \\
$0 \mathrm{~cm}(\mathrm{~s})$ & $230(33)$ & $404(72)$ \\
$60 \mathrm{~cm}(\mathrm{~s})$ & &
\end{tabular}

less intense in Experiment 2 (Table 4). Although fuel moisture and relative humidity differed considerably between the 2 experiments, other weather and fuel conditions were similar. The lower fuel moisture and relative humidity in Experiment 1 resulted in faster rates of spread, greater fireline intensity, and greater values for most time-temperature parameters. However, heat per unit area differed little between experiments.

Effects of Summer Burning on Production and Community Composition

Precipitation was above average in 1989,1 year after burning in Experiment 1, and near normal in 1990, 1 year after burning in Experiment 2 (Table 2). Precipitation was also near normal in
1991, 2 years after burning in Experiment 2. Thus, total herbage production for the experiments was likely near normal since precipitation was near or above normal.

Dry-matter standing crops of little bluestem, other perennial grasses, total perennial grasses, and total herbage averaged over the 2 experiments were reduced the first growing season after late-summer burning (Table 5 ). The burning $X$ year interaction for

Table 5. Standing crop $\left(\mathrm{kg} \mathrm{ha}^{-1}\right)$ of vegetation components the first year and second year following late-summer burning of tallgrass prairie. Values are averaged over experiments.

\begin{tabular}{|c|c|c|c|c|}
\hline \multirow[b]{2}{*}{ Vegetation component } & \multicolumn{2}{|c|}{ Year 1} & \multicolumn{2}{|c|}{ Year 2} \\
\hline & Burned & Unburned & Burned & Unburned \\
\hline & \multicolumn{2}{|c|}{$\ldots(\mathrm{kg} / \mathrm{ha}) \ldots$} & \multicolumn{2}{|c|}{$\ldots(\mathrm{kg} / \mathrm{ha}) \ldots$} \\
\hline Tallgrasses & 1200 & 1430 & 1270 & 1780 \\
\hline Little bluestem & $100^{* *}$ & 650 & $420^{* *}$ & 710 \\
\hline Other perennial grasses & $570^{* *}$ & 990 & 1000 & 850 \\
\hline Total perennial grasses & $1870^{* *}$ & 3070 & 2690 & 3340 \\
\hline Forbs & 1240 & 640 & 460 & 140 \\
\hline Annual grasses & 40 & 20 & 10 & 10 \\
\hline Total herbage & $3150^{*}$ & 3730 & 3160 & 3490 \\
\hline
\end{tabular}

*,**Significant difference between burned and unburned treatments within a year at $P<0.05$ and 0.01 , respectively.

forb standing crop was not significant ( $P>0.95$ ). Averaged over years, unburned plots produced significantly more $(P<0.002)(850$ $\left.\mathrm{kg} \mathrm{ha}^{-1}\right)$ forb standing crop than burned plots $\left(400 \mathrm{~kg} \mathrm{ha}^{-1}\right)$. The annual grass standing crop component was small and did not differ between burn treatments in either year. Standing crop of tallgrasses did not differ between burned and unburned plots in the first or second year after burning. Little bluestem standing crop was less on burned than unburned plots through the second year after burning. No differences in standing crop of other components were detected between burn treatments by the second year.

\section{Effects of Herbicides on Production and Community Composition} Following Burning

No interactions were associated with tallgrasses, little bluestem, other perennial grasses, total perennial grasses, and annual grasses, so the effect of herbicide treatment on these herbage components was averaged over years and experiments (Table 6). The standing

Table 6. Standing crop $\left(\mathrm{kg} \mathrm{ha}^{-1}\right)$ of 5 vegetation components in response to herbicide application following late-summer burning of tallgrass prairie. Values are averaged over years and experiments.

\begin{tabular}{lccc}
\hline & \multicolumn{3}{c}{ Herbicide treatment } \\
\cline { 2 - 4 } Vegetation component & None & Atrazine & $2,4-\mathrm{D}$ \\
\hline & $1240 \mathrm{~b}$ & $1480 \mathrm{~b}$ & $1940 \mathrm{a}$ \\
Tallgrasses & $260 \mathrm{a}$ & $270 \mathrm{a}$ & $360 \mathrm{a}$ \\
Little bluestem & $780 \mathrm{a}$ & $840 \mathrm{a}$ & $920 \mathrm{a}$ \\
Other perennial grasses & $2280 \mathrm{c}$ & $2590 \mathrm{~b}$ & $3220 \mathrm{a}$ \\
Total perennial grasses & $20 \mathrm{ab}$ & $10 \mathrm{~b}$ & $30 \mathrm{a}$ \\
\hline Annual grasses & &
\end{tabular}

Means within a row followed by the same letter do not differ significantly $(P>0.05)$

crop of tallgrasses and total perennial grasses averaged over ycars and experiments was greater on plots treated with 2,4-D than on plots treated with no herbicide or with atrazine (Table 6). Because burning did not result in a large increase in annual grasses, atrazine had little effect on the annual grasses (Table 6). A significant treatment $X$ experiment $X$ year interaction was detected for forbs. Forbs that increased with the late summer burn were partially controlled by 2,4-D (Table 7). Atrazine had little effect on standing crop of forbs (Table 7). Compared to plots with no herbicide application, atrazine reduced forb standing crop only in year 2 of 
Table 7. Standing crop (kg ha $\mathrm{g}^{-1}$ ) of forbs the first year and second year following late-summer burning of tallgrass prairie in response to herbicide application.

\begin{tabular}{lrcc}
\hline \hline & \multicolumn{3}{c}{ Herbicide treatment } \\
\cline { 2 - 3 } & None & Atrazine & $2,4-\mathrm{D}$ \\
\hline Year 1 & $\ldots \ldots \ldots \ldots$ & $(\mathrm{kg} / \mathrm{ha})$ & $\ldots \ldots \ldots \ldots$ \\
Experiment 1 & $1740 \mathrm{a}$ & $2130 \mathrm{a}$ & $750 \mathrm{~b}$ \\
Experiment 2 & $730 \mathrm{a}$ & $770 \mathrm{a}$ & $150 \mathrm{~b}$ \\
Year 2 & & & \\
Experiment 1 & $300 \mathrm{a}$ & $100 \mathrm{~b}$ & $160 \mathrm{~b}$ \\
Experiment 2 & $620 \mathrm{a}$ & $710 \mathrm{a}$ & $150 \mathrm{~b}$ \\
\hline
\end{tabular}

Means within a row followed by the same letter do not differ significantly $(P>0.05)$.

Experiment 1. In all other years, standing crop of forbs on plots treated with 2,4-D was less than on plots treated with atrazine. A treatment $X$ year interaction was present for total herbage. Total herbage in year 2 was greatest on plots treated with 2,4-D (Table 8). However, total herbage standing crop in year 1 was greatest on plots treated with atrazine.

Table 8. Standing crop ( $\mathrm{kg} \mathrm{ha}^{-1}$ ) of total herbage the first year and second year following late-summer burning of tallgrass prairie in response to herbicide application. Values are averaged over 2 experiments.

\begin{tabular}{lcc}
\hline \hline \multicolumn{3}{c}{ Herbicide } \\
\hline None & Atrazine & $2,4-\mathrm{D}$ \\
\hline $\begin{array}{l}\text { Year } 1 \\
3140 \mathrm{ab}\end{array}$ & $3830 \mathrm{a}$ & $3030 \mathrm{~b}$ \\
$\begin{array}{l}\text { Year 2 } \\
3160 \mathrm{~b}\end{array}$ & & \\
\hline
\end{tabular}

Means within a row followed by the same letter do not differ significantly $(P>0.05)$

\section{Discussion and Conclusions \\ Effects of Summer Burning on Production and Community Composition}

The response of tallgrass prairie community composition to fire in late summer appears to be variable. Reduced production of little bluestem and perennial grasses other than tallgrasses to summer fires we noted in these 2 experiments does not always occur. In an earlier study comparing summer burning in grazed and ungrazed tallgrass prairies near our study area, late-summer burning in grazed tallgrass prairie had no effect on tallgrasses and little bluestem. Production of cool-season annual grasses the first year after burning increased, but forbs did not increase until the second ycar after burning (Ewing and Engle 1988, Engle et al. 1992). In that same study, burning in ungrazed prairie reduced little bluestem standing crop, and standing crop of annual forbs was almost 3 times that of the unburned plot the first year after the fire. Total herbage standing crop was not reduced by burning in either grazed or ungrazed plots. In a southcentral Oklahoma ungrazed tallgrass prairie-upland hardwood forest, canopy cover of little bluestem decreased from 83 to $42 \%$ in 1 year following a mid-July fire (Adams et al. 1982). Forb cover decreased from 11 to 6\%, and switchgrass cover increased.

Tallgrasses apparently tolerate growing-season fire. In contrast, the response of little bluestem, forbs, and cool-season annual grasses appears highly variable. Little bluestem will sometimes decrease dramatically, which is common of bunchgrasses containing a high density of dead material within the bunches (Wright 1971). Forbs and cool-season annual grasses will sometimes increase dramatically. Although the study area for these 2 experiments was grazed before the burning treatments were applied, cool-season annual grasses were a minor component and their standing crop remained small following burning. Forbs, primarily common broomweed [Gutierrezia dracunculoides (D.C.) Blake] and western ragweed (Ambrosia psilostachya D.C.), composed about $15 \%$ of the herbage in unburned plots and they increased considerably following burning. Common broomweed increases with a lack of overwintering mulch (Towne and Owensby 1983). Production of common broomweed and western ragweed commonly increases with progressive overgrazing in northcentral Oklahoma tallgrass prairie (Sims and Dwyer 1965), and was doubled after late-summer burning in the grazed tallgrass prairie study of Ewing and Engle (1988). However, we found very little blackeyed susan (Rudbeckia hirta L.), a forb not normally found in abundance in high-seral tallgrass prairie, but abundant in the ungrazed, burned prairie in the Ewing and Engle (1988) study.

Pre-burn community composition and growing conditions before, during, and after burning appear to determine the response of grazed, tallgrass prairies to summer fire more than does fire behavior. Fire behavior in Experiment 1 was similar to fire behavior in the grazed plot of the Ewing and Engle (1988) study, yet post-burn composition and production response of these 2 prairies were different in some aspects important to management. Fires in Experiment 1 were more intense than the fires in Experiment 2, but the vegetation response did not differ between these 2 studies (i.e., no burn treatment $X$ experiment interaction). Bidwell and Engle (1992) found a relationship between fire behavior and response of a grazed tallgrass prairie to spring burning. However, community composition after summer fires is probably influenced to a greater extent by the relative abundance of certain perennial herbaceous plants such as little bluestem that inhabit the site as well as the composition of the seed bank of ruderals capable of germinating and growing in the more open post-fire environment (Ewing and Engle 1988, Abrams 1988).

We observed a significant reduction in herbage production the first year following burning. In contrast, Ewing and Engle (1988) found no reduction in herbage production following late-summer burning nor any differences in soil water content between burned and unburned prairies. Increased runoff and increased evaporative losses have been associated with reduced plant-available water the growing season following winter and early spring burning (Anderson et al. 1970, Towne and Owensby 1984), which leads us to conclude that our burning treatments resulted in less plantavailable water.

Herbage production following burning is dependent largely on the amount of plant-available water in the growing season. Humid sections of the tallgrass prairie and mesic sites in the tallgrass prairie generally do not experience reductions in herbage production following fire whereas reduction in herbage production is likely after fire in more arid prairies and grasslands (Owensby 1985, Abrams et al. 1986). Although herbage production following spring burning generally increases, the production can vary from -20 to $+250 \%$, with burning increasing production when water is adequate (Risser et al. 1981, p. 417-420). Abrams et al. (1986) found that late spring burning on deep soils in the Flint Hills of Kansas stimulated herbage production. In contrast, burning on shallow soils exhibited no herbage production response, possibly because of increased water stress accompanying increased evapotranspiration with the loss of litter from the soil surface. Tallgrass prairies in the Kansas Flint Hills experience lower soil moisture levels and lower herbage production after winter and early spring burning compared to unburned prairies and prairies burned in late spring (McMurphy and Anderson 1965, Anderson et al. 1970).

This study has application to burns prescribed for the growing season. Summer burning has been suggested as a more effective brush control treatment than dormant-season burning in tallgrass 
prairies (Anderson 1981). Although a late-winter burn reduced deciduous woody plants more than a summer burn in southcentral Oklahoma (Adams et al. 1982), late-summer burning of dense stands of nonspouting juniper was very effective for controlling juniper when they were pretreated with a desiccating herbicide (Engle and Stritzke 1991). We conclude that late-summer burning in high-seral tallgrass prairie is a potential alternative to dormant season burning since late-summer burning did not severely reduce herbage production nor drastically alter community composition for more than 1 year after the burn.

\section{Using Herbicides after Summer Fires in High-Seral Tallgrass Prairie}

Our results indicate that $2,4-\mathrm{D}$ is an effective and more consistent treatment than atrazine for reducing forb production following late-summer burning. Atrazine and 2,4-D have both been used to reduce forb standing crop and increase perennial grass standing crop in low and mid-seral tallgrass prairies (Powell et al. 1982, Gillen et al. 1987, Rice and Stritzke 1989) and atrazine has been used to reduce western ragweed production in high-seral tallgrass prairie (Baker et al. 1980). However, both herbicides have been ineffective in some situations. Neither atrazine (Masters et al. 1992) nor 2,4-D (Powell et al. 1982) provided any meaningful forb control on high-seral tallgrass prairies. Atrazine inconsistently reduced forb production in a mid-seral tallgrass prairie that contained equal components of western ragweed and slimflower scurfpea (Psoralea tenuiflora Pursh), the latter of which is resistant to atrazine even at high rates (Gillen et al. 1987). Unlike 2,4-D, atrazine will reduce cool-scason annual grasses and increase perennial grass standing crop on low and mid-seral tallgrass prairies (Samson and Moser 1982, Waller and Schmidt 1987, Gillen et al. 1987). However, atrazine was of little value in this study as a follow-up to the late-summer burns, in part because of the small amount of cool-season annual grasses and because of the relatively large perennial grass component following the late summer fires. Atrazine application would not be a desirable management practice following late summer burning when the primary weedy plants are forbs rather than annual grasses. We found 2,4-D consistently reduced forb production more than atrazine following the late summer fires.

Although forbs were not reduced by atrazine in the first year after burning, plots treated with atrazine produced more perennial grasses than plots with no herbicide, and atrazine-treated plots produced more total herbage than plots with no herbicide or plots treated with 2,4-D in the first year after late-summer burning. Previous studies have shown atrazine alone or in combination with spring burning increased production of perennial grasses and total herbage on tallgrass prairies unless the decrease in production of forbs or annual grasses was large (Baker and Powell 1978, Waller and Schmidt 1983, Rehm 1984, Gillen et al. 1987, Engle et al. 1990).

For high-seral tallgrass prairies burned in late summer, 2,4-D appcars to be a suitable option for controlling undesirable forbs if the land-use objective is to produce grass for cattle grazing. Application of 2,4-D will result in reliable control of forbs and a favorable production response from the perennial grasses, especially tallgrasses. Because an increase in forbs represents improved habitat for certain wildlife species including bobwhite quail (Colinus virginianus) (Guthrey 1986), no follow-up treatment should be applied if wildlife habitat improvement is a management objective.

\section{Literature Cited}

Abrams, M.D. 1986. Historical development of gallery forests in northeast Kansas. Vegetatio 65:29-37.

Abrams, M.D. 1988. Effects of burning regime on buried seed banks and canopy coverage in a Kansas tallgrass prairie. Southwest. Natur. 33:65-70.
Abrams, M.D., A.K. Knapp, and L.C. Hulbert. 1986. A ten-year record of aboveground biomass in a tallgrass prairie: effects of fire and topographic position. Amer. J. Bot. 73:1509-1515.

Adams, D.W., R.C. Anderson, and S.L. Collins. 1982. Differential response of woody and herbaceous species to summer and winter burning in an Oklahoma grassland. Southwest. Natur. 27:55-61.

Anderson, K.L., E.F. Smith, and C.E. Owensby. 1970. Burning bluestem range. J. Range Manage. 23:81-92.

Anderson, R.C. 1972. Prairie history, management and restoration in southern Illinois. p. 15-22. In: J. Zimmerman, ed. Proc. Second Midwest Prairie Conference. Madison, Wisc.

Anderson, R.C. 1981. An evolutionary model summarizing the roles of fire, climate, and grazing animals in the origin and maintenance of grasslands: an end paper, p. 295-305. In: Grasses and grasslands: systematics and ecology. Univ. Oklahoma Press, Norman, Okla.

Baker, R.L., and J. Powell. 1978. Oklahoma tallgrass responses to atrazine with 2,4-D and fertilizer. Proc. First Int. Rangeland Cong. p. 681-683.

Baker, R.L., J. Powell, R.D. Morrison, and J.F.Stritzke. 1980. Effects of atrazine, 2,4-D and fertilizer on crude protein content of Oklahoma tallgrass prairie. J. Range Manage. 33:404-407.

Bidwell, T.G., D.M. Engle, and P.L. Claypool. 1990. Effects of spring headfires and backfires on tallgrass prairie. J. Range Manage. 43:209-212.

Bidwell, T.G., and D.M. Engle. 1991. Behavior of headfires and backfires on tallgrass prairie. p. 344-350. In: S.C. Nodvin and T.A. Waldrop (eds.). Fire and the Environment: Ecological and Cultural Perspectives. Proc. of an International Symposium. USDA Forest Serv. Gen. Tech. Rep. SE-69.

Bidwell, T.G., and D.M. Engle. 1992. Relationship of fire behavior to tallgrass prairie herbage production. J. Range Manage. 45:579-583.

Bragg, T.B. 1982. Seasonal variations in fuel and fuel consumption by fires in a bluestem prairie. Ecology 63:7-11.

Bragg, T.B., and L.C. Hulbert. 1976. Woody plant invasion of unburned Kansas bluestem prairic. J. Range Manage. 29:19-24.

Britton, C.M., B.L. Karr, and F. Sneva. 1977. A technique for measuring rate of fire spread. J. Range Manage. 30:395-397.

Byram, G.M. 1959. Combustion of forest fuels. p. 61-89. In: K.M. Davis (ed.). Forest fire: Control and use. McGraw Hill, N.Y.

Carmer, S.G., W.E. Nyquist, and W.M. Walker. 1989. Least significant differences for combined analyses of experiments with two- and threefactor treatment designs. Agron. J. 81:665-672.

Engle, D.M., T.G. Bid well, A.L. Ewing, and J.R. Williams. 1989. A technique for quantifying fire behavior in grassland fire ecology studies. Southwest. Natur. 34:79-84.

Engle, D.M., T.G. Bidwell, J.F. Stritzke, and D. Rollins. 1990. Atrazine and burning in tallgrass prairie infested with prairie threeawn. J. Range Manage. 43:424-427.

Engle, D.M., T.G. Bidwell, and A.L. Ewing. 1992. Effects of late summer fire in tallgrass prairie. p. 9. In: T.G. Bidwell (ed.). Range research highlights. Coop. Ext. Serv. Oklahoma State Univ. Circ. E-905, Stillwater.

Engle, D.M., and J.F. Stritzke. 1991. Fire-herbicide systems for manipulating juniper. p. 397-401. In: S.C. Nodvin and T.A. Waldrop (eds.), Fire and the environment: Ecological and cultural perspectives: Proc. of an International Symposium. Gen. Tech. Rep. SE-69. USDA Forest Serv., Southeastern Forest Exp. Sta.

Ewing, A.L., and D.M. Engle. 1988. Effects of late summer fire on tallgrass prairie microclimate and community composition. Amer. Midl. Natur. 120:212-223.

Gillen, R.L., D. Rollins, and J.F. Stritzke. 1987. Atrazine, spring burning, and nitrogen for improvement of tallgrass prairie. J. Range Manage. 40:444-447.

Guthrey, F.S. 1986. Beef, brush, and bobwhites: quail management in cattle country. Caesar Kleberg Wild life Res. Institute, Texas A\&I Univ., Kingsville.

Launchbaugh, J.L., and C.E. Owenshy. 1978. Kansas rangelands: their management based on a half century of research. Kansas Agr. Exp. Sta. Bull. 622. Manhattan.

Masters, R.A., K.P. Vogel, and R.B. Mitchell. 1992. Response of central plains tallgrass prairies to fire, fertilizer, and atrazine. J. Range Manage. 45:291-295.

McMurphy, W.E., and K.L. Anderson. 1965. Burning Flint Hills range. J. Range Manage. 18:265-269.

Meyers, H.R. 1982. Climatological data of Stillwater, Oklahoma 1893-1980. Okla. Agr. Exp. Sta. Res. Rep. P-821. 
Owensby, C.E. 1985. Fire and tallgrass prairie. p. 252-270. In: L.D. White, D.E. Guynn, and T.R. Troxel (eds.). Proc. Int. Ranchers Roundup. Texas A\&M Univ. and Texas Agr. Res. and Ext. Center, Uvalde.

Owensby, C.E., and E.F. Smith. 1979. Fertilizing and burning Flint Hills range. J. Range Manage. 32:254-258.

Powell, J., J.F. Stritzke, R.W. Hammond, and R.D. Morrison. 1982. Weather, soil and 2,4-D effects on tallgrass prairie on Oklahoma. $J$. Range Manage. 35:483-488.

Rehm, G.W. 1984. Yield and quality of a warm-season grass mixture treated with N, P, and atrazine. Agron. J. 76:731-733.

Rice, C.K., and J.F. Stritzke. 1989. Effects of 2,4-D and atrazine on degraded Oklahoma grasslands. J. Range Manage. 42:217-222.

Risser, P.G., E.C. Birney, H.D. Blocker, S.W. May, W.J. Parton, and J.A. Wiens. 1981. The true prairie ecosystem. US/IBP Synthesis Series 16, Hutchinson Ross Publ. Co., Stroudsburg, Penn.

Rothermel, R.C., and J.E. Deeming. 1980. Measuring and interpreting fire behavior for correlation with fire effects. USDA Forest Serv. Gen. Tech. Rep. INT-93.

Samson, J.F., and L.E. Moser. 1982. Sod-seeding percnnial grasses into eastern Nebraska pastures. Agron. J. 74:1055-1060.
SAS Institute Inc. 1988. SAS/ STAT user's guide, release 6.03 edition. SAS Institute, Inc., Cary, N.C.

Sims, P.L., and D.D. Dwyer. 1965. Pattern of retrogression of native vegetation in north central Oklahoma. J. Range Manage. 18:20-25.

Towne, G., and C. Owensby. 1983. Annual broomweed [Gutierrezia dracunculoides (DC.) Blake] response to burning and mulch addition. J. Range Manage. 36:711-712.

Towne, G., and C. Owensby. 1984. Long-term effects of annual burning at different dates in ungrazed Kansas tallgrass prairie. J. Range Manage. 37:392-397.

USDA Soil Conservation Service. 1981. Land resource regions and major land resource areas of the United States. Agr. Handb. 296, USDA Soil Conserv. Serv., U.S. Gov. Print. Off., Washington, D.C.

Waller, S.S., and D.K. Schmidt. 1983. Improvement of eastern Nebraska tallgrass range using atrazine and glyphosate. J. Range Manage. 36:87-90.

Wright, H.A. 1971. Why squirreltail is more tolerant to burning that needle-and-thread. J. Range Manage. 24:277-284. 